\title{
Civil Judge in Uganda: Remuneration Systems and Promotion Possibilities. How to Reward Efficient and Independent Decisions
}

\author{
Asiimwe Jackline-Bainipai*
}

\begin{abstract}
This piece of work is discusses the systems of remuneration of judges and promotion possibilities as well as rewarding efficient and independent decisions in Uganda. The research finds that whereas these three form part and parcel of the core of an independent judiciary, and whereas there are adequate legal provisions, the enforceability is lacking due to the fact that there are high levels of interference by the executive in the function of the judiciary. The remuneration, reward of an efficient judge are largely dependent on paying allegiance to the executive and deciding cases in appeasement of the executive. Yet, the remuneration, promotion and reward are supposed to be on merit. They should also be established by law and not subject to arbitrary interference from the executive. This study has revealed how the executive has substantial impact on remuneration, promotion and reward of efficient judges. Judges that decide cases according to the law irrespective of the interests of the executive are sidelined in the promotions, remunerations and reward. The study makes relevant conclusions and recommendations.

"The remuneration of the judges is not sufficient to induce the ablest lawyers in the prime of life to accept judicial office. If that state of affairs is allowed to continue it must have serious effect upon the administration of the law. It will impair those intellectual standards which have made our English legal system a great legal system; it will tend to impair that law abiding instinct which is the condition precedent for the maintenance of a high standard of civilization, and it will weaken the chief remaining guarantee for the prosecution of the liberties of that subject."
\end{abstract}

With reflection on the above statement on remuneration, this piece of work discusses remuneration systems and promotion possibilities and how to reward efficient and independent judges from the Ugandan perspective.

* About the Author: Asiimwe Jackline is currently a Lecturer at Islamic University in Uganda (Kampala Campus), Co-founder and Director Center for East African Regional Integration, Legal Advisor Lead4Tomorrow (Uganda), as well as a Researcher. She has previously served as a Legal Researcher Attached to Court of Appeal and Supreme Court, Legal Consultant with TrustAfrica-Senegal and AWEPA South Sudan. Email: asiimwejackline4@yahoo.com.

1 Holdsworth LQR p 33. See, Ramon Mullerat OBE "The Judges Independence from his own Convictions" in The Indian Advocate: Journal of the Bar Association of India: Vol XXXII $2004 \mathrm{p}$ 88. 


\section{A. Introduction}

The judiciary of Uganda, just like other public sectors is weighed down by many challenges ranging from low pay, selective promotions, low morale, understaffing, case back$\log$ among others. This situation is worsened by the violation of judicial independence and immunity which judicial officers ought to enjoy in the course of discharging their judicial duties. ${ }^{2}$ In Uganda today, given the earnings enjoyed by most successful legal practitioners, the choice to give up juicy opportunities for a judicial appointment is a service to a nation rather than a priority. It is unrealistic to compare the income of a senior legal practitioner to judicial remuneration. Therefore, an attractive remuneration package is essential for attracting and retaining the best brains and to reduce the chances of judges being vulnerable to corruption as well as put an end to frequent industrial action by aggrieved judicial officers. ${ }^{3}$ In spite of these challenges, to its credit the judiciary carries on.

Noteworthy, enhanced remuneration and merit based promotion carried out on are key to safeguarding the independence of judiciary. This work reveals gaps in law, highlights areas of unrealized potential and suggests ways in which the law might develop to more comprehensively protect remuneration and promotion possibilities of judges at all levels in the judiciary. The importance of judicial independence is bolstered by its inherent relationships with democracy, the separation of powers and the rule of law. Ultimately, my analysis highlights the importance of judicial vigilance in respect of remuneration and promotion possibilities facets of judicial independence.

This piece of work is divided into eight sub sections namely:

(i) The Remuneration of Judges in Uganda;

(ii) The Protection Remuneration of judges in Uganda;

(iii) Challenges to Adequate Remuneration of Judges in Uganda;

(iv) Promotion Possibilities of Judges in Uganda;

(v) The Law on Promotion Possibilities of Judges in Uganda;

(vi) Challenges to the Promotion Possibilities of Judges in Uganda;

(vii) Conclusion, and

(viii) Recommendation.

\section{Remuneration of Judges in Uganda}

Remuneration refers to pay for services rendered or work done. ${ }^{4}$ A sufficient salary is a necessary safeguard against the risk that impoverished judges will be compelled to sell justice

2 Michael J Beloff QC, Paying Judges: Why, Who, Whom, How Much? Neil Lecture, 2006, Published in the Lord Denning Journal.

3 Asiimwe, J., Towards God Governance in Uganda: A Critical Analysis of the Role Played By Judiciary in Promoting Rule of law from a Constitutional Perspective, Dissertation, University of Dar es Salaam, August, 2013, p.62.

4 Merrian Webster's Learners Dictionary. 
to make ends meet. The inspiration for any form of judicial payment is rooted in the consideration that judges who were not paid could be bought. ${ }^{5}$ In addition, salary often correlates with prestige which can help protect judges against attempts at improper influence especially from parties to disputes. ${ }^{6}$

In the life of the judiciary, financial autonomy is fundamental and without it, the executive can seriously impact upon judicial independence by limiting judiciary's access to funds passed by Parliament or assuming control of services and staff upon which judiciary depends. Providing budgetary independence enables the judiciary to control its own funds and to make use of them in accordance with its set priorities. ${ }^{7}$

Although judicial salaries need not match those of the political branch exactly, ensuring equivalent salaries usefully reinforces the perception of equality among the separate branches. International standards variously call for salaries to be commensurate with the dignity of the profession or simply adequate. ${ }^{8}$ Judicial remuneration should be enhanced to reflect the professional skill and responsibilities of a judge and should guard against financial inducements or conflicts of interest that might lead a judge to compromise his or her independence. In Uganda judges receive lower pay than members of parliament or civil servants in leading positions. ${ }^{9}$ On several occasions judges strike to compel the government to consider increment in their salaries to no avail irrespective of various legal provisions.

\section{Protection of Remuneration of Judges in Uganda}

Judicial independence requires financial security. Indeed the Constitution ${ }^{10}$ has elaborate provisions on remuneration of judges in Uganda. In the same vein, the Constitution ${ }^{11}$ provides that the administrative expenses shall be charged on the consolidated fund, the judiciary is self-accounting and that judges salaries, allowances, privileges and retirement bene-

5 Michael J Beloff QC, Paying Judges: Why, Who, Whom, How Much? Neil Lecture, 2006, Published in the Lord Denning Journal.

6 Monitoring the EU Accession Process: Judicial Independence, 2001, Central European University Press, Hungary, p.48.

7 Supra note 5.

8 UN Basic Principles, Article 11 (where adequate means that it must "ensure that the Judge has true economic independence...”.).

9 Members of Parliament in Uganda are currently earning UX 24 million (approximately US\$ 6486.

10 Article 128(5) The administrative expenses of the judiciary, including all allowances, gratuities and pensions payable to or in respect of persons serving in the judiciary, shall be charged on the Consolidated Fund.

(6) The Judiciary shall be self-accounting and may deal directly with the ministry responsible for finance in relation to its finances.

(7) The salary, allowances, privileges and retirement benefits and other conditions of service of a judicial officer or other person exercising judicial power shall not be varied to his or her disadvantage.

11 Article 128 (5), (6) and (7). 
fits and their conditions for service shall not be varied to his or her disadvantage. It is unconstitutional for Parliament to reduce the judicial salary scale overall to the extent that it threatens judges' independence. And no judge can be appointed unless provision is made for his or her salary. These are guarantors of independence, but they are not, by themselves, guarantors of excellence.

The Constitution of the Republic of Uganda makes provision for protection of workers' rights including equitable employment terms and conditions. ${ }^{12}$ Specifically, the law mandates Parliament to enact laws to provide for rights of persons to work under safe and healthy conditions, and to ensure equal pay for equal work without discrimination. ${ }^{13}$

Similarly, the Salaries \& Allowances (Specified Officers) Act $1999^{14}$, makes provision for salary, allowances and benefits for judges.

In 2006, Parliament enacted the Employment $\mathrm{Act}^{15}$ in fulfillment of the aforementioned provision. Under Section 6(6) thereof, the minister and labour advisory board seek to give effect to the principles of equal remuneration for employees for equal value. In addition Section 6(7) requires every employer to pay equal remuneration for work of equal value regardless of whether they are public or private.

In addition, the Labour Unions Act,${ }^{16} 2006$ introduces a number of rights for employees to demand for their rights among which includes equal pay for work of equal value. The Act guarantees employees the right to organize themselves into labour unions and participate in the management of the said unions. In this regard, judges founded the Uganda Judicial Officers Association (UJOA). ${ }^{17}$

In 2010, the Equal Opportunities Commission was inaugurated in accordance with the Equal Opportunities Commission Act $^{18}$, to give effect to the State's constitutional mandate to eliminate discrimination and inequalities against any individual or group of persons on the ground of sex, age, colour, ethnic origin, tribe, birth, creed or religion, health status, social or economic standing, political opinion or disability, and take affirmative action in favour of groups marginalized on the basis of gender, age, disability or any other reason created by history, tradition or custom for the purposes of redressing imbalances which exist against them; and to provide for other related matters. ${ }^{19}$

As such, whereas the provisions reflect those in many democracies in the world, these provisions remain hollow and rhetoric. The judiciary continues to be poorly remunerated. ${ }^{20}$

12 Article 21.

13 Article 40(1) (b).

14 Cap.291.

15 Employment Act of 2006.

16 Act No.7 of 2006.

17 UJOA is an umbrella association through which judicial officers can channel their grievances.

18 Act No.2of 2007.

19 Salaries and Allowances (Specified Officers) Act Cap 291.

20 Supra (interview with anonymous judicial officer.). 
That as it may be, Ugandan Judiciary is the least paid in the region ${ }^{21}$ according to the current pay structure. ${ }^{22}$ The judicial officers under the umbrella body, the Uganda Judicial Officers Association (UJOA) have several times laid down their tools demanding for salary increment, transport, housing allowances and security among others. On several accounts the judges have suspended strikes as government promises to increase their salaries. ${ }^{23}$ However, their grievances to date have not been addressed leading the judiciary to strike year in out.

In that regard, 2017, UJOA proposed the following pay rise for judicial officers to uphold the independence of the judiciary as shown in the table below.

Table I: Table Showing Current pay for judicial officers and the anticipated pay in the 2018/2019 financial Year (Millions of Uganda Shillings (The current rate dollar rate to shilling is US\$1: UGX 3812.)

\begin{tabular}{|l|l|l|}
\hline $\begin{array}{l}\text { Position Held } \\
\text { (November 2018) }\end{array}$ & $\begin{array}{l}\text { Current Pay } \\
\text { (as at November. 2018) } \\
\text { (Millions of UGX/month }\end{array}$ & $\begin{array}{l}\text { Anticipated Pay } \\
\text { (2019/2020 Financial Year) } \\
\text { (Millions of UGX/month) }\end{array}$ \\
\hline Chief Justice & 20 & 55 \\
\hline Deputy Chief Justice & 18 & 53 \\
\hline Principal Judge & 10 & 50 \\
\hline Justices of Supreme Court & 9 & 34 \\
\hline Justices of Court of Appeal & 9 & 33 \\
\hline High Court Judges & 8 & 31 \\
\hline Chief Registrar & 4 & 27 \\
\hline Registrars & 4 & 23 \\
\hline Deputy Registrars & 4 & 21.5 \\
\hline Assistant Registrars & 3 & 20 \\
\hline Chief Magistrate & 2.8 & 17 \\
\hline Principal Magistrate Grade I & 2.4 & 14 \\
\hline Senior Principal Magistrate Grade I & 1.5 & 13 \\
\hline Senior Magistrate Grade I & 1.5 & 12 \\
\hline Magistrate Grade I & 1.2 & 13 \\
\hline Senior Principal Magistrate & 1.5 & 12 \\
\hline
\end{tabular}

Source: UJOA website.

21 Mr. Kaweesa Godfrey, President Uganda Judicial Officers Association (UJOA), May 2017.

22 About two years ago, government selectively increased salaries of Chief Justice and Deputy chief justice to UX 20 million and UX 18 million respectively, a move that angered other judicial officers who were left out.

23 Nicolas Bamulanzeki, Judges suspend Strikes as Government agrees to Increase Salaries, The Observer, September 6, 2017. 
The UJOA president Godfrey Kaweesa stated that the increment of salaries for heads of the judiciary is justified, saying that it should match that of the Kenyan Chief Justice whose monthly pay is approximately KX 1.3 million. Kaweesa also cited the increased cost of living leading to increased corruption incidents as grounds for increase of salaries across board for all judicial officers. Under the new salary structure which came into force in January 2017, the Chief Justice earns a monthly pay of UGX 20 million while his deputy UGX 18 million. This was a salary increment of two top judicial officers excluding all others. Prior to the discriminatory pay rise of January 2017, the last time the judiciary increased the pay for judicial officers was in 2013. ${ }^{24}$

In spite of the judges' persistent demands to have a pay enhancement, the government has failed to honour her numerous promises to have this rise effected. Thus, the 2017/2018 financial budget only took into consideration a pay increase for the Chief Justice and the Deputy Chief Justice. ${ }^{25}$ The Legal Parliamentary Affairs Committee has made a number of recommendations that government has not yet implemented. They include lifting of the presidential moratorium of salary increment in order to cater for judicial officers and other justice law and order sector staff whose salaries have been affected by inflation and high cost of living. ${ }^{26}$

Most judges have resorted to farming as a source of an additional income to sustain their families. Two of the justices of appeal that I interviewed confessed that without additional source of income for instance, farming, it is very difficult to adequately meet the needs of their families. ${ }^{27}$

The judges highlighted five key areas which need to be addressed by government shall have the effect of stimulating the administration of justice in Uganda namely; salary increment, transport, medical insurance, housing, security and medical insurance should be provided to all judicial officers if court performance is not to be affected. ${ }^{28}$

Judicial salaries and pensions should be adequate and commensurate with the dignity of the office, and should not be decreased during a judge's tenure. They should also be established by law and not subject to arbitrary interference from the executive. ${ }^{29}$

It should be noted that the Constitution expressly stipulates that the emoluments of the President cannot be subjected to tax deductions, it remains silent as to the fate of the remuneration of the judicial officers. As such, just like other citizens, the judge's 'inadequate

24 Before this 2013 increase, then Chief Justice Benjamin Odoki lamented of how the monthly pay of Ug.Shs 5 million that he was earning was equivalent to the pocket change for a lawyer in private practice.

25 Anthony Wesaka, Judges Protest Exclusion from Pay Rise. Daily Monitor May 22018.

26 Ibid.

27 Interview with anonymous Justices of Supreme Court on the $22^{\text {nd }}$ October 2018.

28 Interview with Magistrate Grade One Ms. Sarah Nantogo conducted on 29/10/2018. In other interviews conducted with 4 other Magistrates Grade One, Two Registrars and a High Court Judge who preferred to remain anonymous, they all shared similar views.

29 Supra. 
pay' is subject to taxation. It is now a settled position that there is no wrong in judges paying taxes as is for the other citizens. In this regard, the Supreme Court of Uganda in the case of Attorney General of the Republic of Uganda v. Masalu Musene Wilson \& Ors $^{30}$ the Supreme Court overruled the decision of the constitutional which had found that the remuneration of judges is not taxable. The Supreme Court relying on O'Malley v. Woodrough $^{31}$ where the Supreme Court of the United States adopted the reasoning of the dissenting Justices in Evans ${ }^{32}$ that Judges are not immune from sharing with other citizens the material burden of the government, and therefore their payment of a non-discriminatory tax laid generally on all citizens was not a diminution of Judges' salaries. However, it should be noted that salary, compensation and promotion possibilities are not necessarily the key determinants of overall job satisfaction though significant factors.

The return to private practice, appointment to other office, inadequate salary, and dissatisfaction with office were the most commonly stated motivations for leaving the bench. ${ }^{33}$ They also noted that there was likely overlap between resignations motivated by "inadequate salary, return to private practice and dissatisfaction with office.

Judicial compensation should reflect the importance and the value of judges to the judicial system. If qualified judges do not find judgeships to be attractive career options, the quality of the judiciary will decline. Experienced judges will be reluctant to remain on the bench if compensation does not provide adequate monetary recognition of the importance of their role in the judicial system. ${ }^{34}$ This could have long-lasting detrimental effects not only on the attraction of the best candidates but also on the morale of the current judiciary, and its performance could suffer as a result

Table II: Monthly Salary for selected Specified Officers for Financial Year 2016/2017

\begin{tabular}{|l|l|}
\hline Designation & $\begin{array}{l}\text { Monthly Salary, FY 2015/16 } \\
\text { (UGX) }\end{array}$ \\
\hline Chief Justice & $11,560,150$ \\
\hline Deputy Chief Justice & $10,532,581$ \\
\hline Principal Judge & $10,018,796$ \\
\hline Justice of Supreme Court & $9,688,506$ \\
\hline Justice of Court & $9,358,216$ \\
\hline Justice of High Court & $9,026,743$ \\
\hline Director of Public Prosecution & $9,026,743$ \\
\hline
\end{tabular}

30 Supreme Court Constitutional Appeal No.07 of 2005.

31307 US 277 (1939).

32 Evans v. Gore, Acting Collector of Internal Revenue 253 US 245(1920), Overruled in United States v. Terry J Hatter, JR. Judge, US District Court 532 US (2001).

33 Interview with Justice of Court of Appeal.

34 Supra. 


\begin{tabular}{|l|l|}
\hline Designation & $\begin{array}{l}\text { Monthly Salary, FY 2015/16 } \\
\text { (UGX) }\end{array}$ \\
\hline Auditor General & $36,100,000$ \\
\hline Inspector General of Government & $17,875,000$ \\
\hline Deputy Inspector General of Government & $15,005,000$ \\
\hline Chairperson of Commission & $8,457,300$ \\
\hline Deputy Chairperson of Commission & $8,157,300$ \\
\hline Members of Commission & $8,007,300$ \\
\hline Inspector General of Police & $6,868,005$ \\
\hline Deputy Inspector General of Police & $6,774,345$ \\
\hline Commissioner of Prisons & $6,868,005$ \\
\hline Deputy Commissioner of Prisons & $6,774,345$ \\
\hline
\end{tabular}

Source: Ministry of Public Service Salary Structure, 2016/2017

The above table shows average salary for the seventeen officers in this category is UGX 11.182 million and yet only six officers (35\%) earned salaries above that average. This is an indication of a wide skew upwards by few officers. Similarly, the difference (UGX 29 million) between the highest paid (UGX 36 million) and the Least paid (UGX 6.7 million) in such a small sample indicate wide disparities. It is important to note the recent revision of salaries of Chief Justice and deputy Chief Justice from from an average of UGX 11,500,000 per month and UGX $10,500,000$ to UGX $20,000,000$ and UGX 18,000,000 respectively. However, the above increment did not cut across other levels in the legal profession.

Table III: Allowances and Benefits for Judges

\begin{tabular}{|l|l|l|}
\hline Category & Allowance (UGX) & Benefits \\
\hline Chief Justice & Medical allowance of 3,600,000 per year & $\begin{array}{l}\text { Furnished house. Chauffeur } \\
\text { driven car; security; travel } 1^{\text {st }} \\
\text { class }\end{array}$ \\
\hline $\begin{array}{l}\text { Deputy Chief } \\
\text { Justice }\end{array}$ & $\begin{array}{l}\text { Housing allowance of 2,500,000 per } \\
\text { month, Medical allowance of 3,000,000 } \\
\text { per year. }\end{array}$ & $\begin{array}{l}\text { Transport: Chauffeur driven } \\
\text { car, security, travel } 1^{\text {st }} \text { class }\end{array}$ \\
\hline Principal Judge & $\begin{array}{l}\text { Housing allowance of 2,300,000 per } \\
\text { month Medical allowance of 3,000,000 }\end{array}$ & $\begin{array}{l}\text { Transport: Chauffeur driven } \\
\text { car, security, travel } 1^{\text {st }} \text { class }\end{array}$ \\
\hline $\begin{array}{l}\text { Justice of the } \\
\text { Supreme Court }\end{array}$ & $\begin{array}{l}\text { Housing allowance of 2,200,000 per } \\
\text { month. Medical allowance of 2,400,000 } \\
\text { per year }\end{array}$ & $\begin{array}{l}\text { Transport: Chauffeur driven } \\
\text { car, security, travel club class }\end{array}$ \\
\hline $\begin{array}{l}\text { Justice of the Court } \\
\text { of Appeal }\end{array}$ & $\begin{array}{l}\text { Housing allowance of 2,100,000 per } \\
\text { month. Medical allowance of 2,400,000 } \\
\text { per year }\end{array}$ & $\begin{array}{l}\text { Transport: Chauffeur driven } \\
\text { car, security, travel club class }\end{array}$ \\
\hline
\end{tabular}




\begin{tabular}{|l|l|l|}
\hline Category & Allowance (UGX) & Benefits \\
\hline Judge of High Court & $\begin{array}{l}\text { Housing allowance of 2,000,000 per } \\
\text { month. Medical allowance of 2,400,000 } \\
\text { per year }\end{array}$ & $\begin{array}{l}\text { Transport: Chauffeur driven } \\
\text { car, security, travel club class }\end{array}$ \\
\hline
\end{tabular}

Source: Extracts from the Second Schedule to Salaries and Allowances (Specified Officers) Act 1999, Cap.291 (Part I. Allowances and benefits for judges.)

\section{B. Law Relating to Promotion Possibilities for Judges in Uganda}

The Judicial Service Commission (JSC) is the body clothed with a constitutional mandate to advise the President in the exercise of president's powers to appoint persons to hold the office of the Chief Justice, the Deputy Chief Justice, the Principal Judge, a justice of the Supreme Court, a justice of Appeal, a judge of the High Court, the office of Chief Registrar and a registrar. ${ }^{35}$ In summary, the JSC makes recommendation as to candidates fit to serve as a judge, the president appoints and Parliaments approves through a vetting process. It should be noted that the same procedure is followed in promotion of judges. The members of the judicial service commission are appointed by the president. ${ }^{36}$ The president thus has influence over the judicial service Commission as the appointing authority. ${ }^{37}$ As such, the constitutional independence granted to the JSC is only rhetoric. The Government representation by inclusion of of the Attorney general as ex officio is politicizing and jeopardizing the independence if any of the JSC. The commission advertises, the judges apply and then they are called for interviews and those who are successful, their names are submitted to the president who appoints them. Then the president sends the names to the parliament for approval.

To Kanyeihamba, the JSC, Parliament and the President can determine the composition of persons appointed as judicial officers which is different from controlling its independence. Kanyeihamba explains that the ethics of the legal profession and the strict discipline of Bar etiquette are the controlling force behind the judiciary. ${ }^{38}$ Although there is involvement of senior judicial officers in the appointment and promotion process because of their experience together with personal knowledge of potential candidates, the president's influence as to the choice of the membership of the Commission remains a big challenge.

On the other hand, the president directly interferes with judges in the performance of their roles. In 2005, the president directed an end to evictions of bona fide occupants of land and threatened to sack judges who did not abide by his edict by issuing what he called

35 Article 147(1)(a) \& (3)(a)(b).

36 Article 142(1) read together with Article 146(2) of the Constitution of Republic of Uganda, 1995 (as amended). Section 3 of the Judicial Service Act, 1997, the chairperson of the JSC shall be appointed by the president with approval of parliament.

37 Article 146.

38 Kanyeihamba, G.W., Kanyeihamba's Commentaries on Law, Politics and Governance, Renaissance Media Ltd, 2006, Kampala, p.67. 
bogus eviction warrants. ${ }^{39}$ In 2007, the president publically proclaimed that the judiciary was staffed with sympathizers of Democratic Party (DP) (one of the prominent opposition political parties) and he would soon sort them out. ${ }^{40}$ It can almost be predicted what would be the fate of these judges when it comes to promotion by the president; they would be sidelined as a form of revenge for not finding in favour of the NRM.

The procedure for appointment and promotion of judges is laid down in the Judicial Service Commission Regulations. ${ }^{41}$ Regulation 15 provides for filling of vacancies; where a vacancy occurs, the chief Justice shall report to the JSC. The Chief Justice forwards a list of all judicial officers in relevant posts who are available to fill the specified vacancies. Regulation 16 provides for advertisement of vacant post. Regulations 17 and 19 provide for appointments; the commission advises the appointing authority, vacancies are to be filled after examination or interview conducted and those who qualify are recommended to the president for appointment or promotion. It is the President who appoints and the Parliament vets the candidates as to fitness to be appointed as judicial officers. On several occasions, persons fit to be appointed as judges are recommended and the president simply ignores them.

This was the case in 2012/2013, where in spite the JSC having selected and made recommendations to the president the person to occupy the position of the Chief Justice, the position remained vacant. In fact, the president wanted to re-appoint the former chief justice Benjamine Odoki who has been an 'NRM' chief justice. The president's attempts to re-appoint Odoki chief justice was blocked by a majority constitutional court ruling. ${ }^{42}$ In a dissenting opinion, Justice Ruby Opio attempted to twist the arm of the law beyond its bendability in vein. The Court in a decision of majority ruled that it was unconstitutional to reappoint Odoki Chief Justice who had clocked the retirement age.

\section{Challenges Relating to Promotion Possibilities and reward of Efficient Judges in Uganda}

Notwithstanding the legal provisions regulating appointment and/or promotion opportunities for judges in Uganda, there are a number of challenges. The process of appointment and/or promotion to higher courts is inherently political, and because appointment to these courts is effectively a form of promotion from lower courts, lower court judges may feel incentives to rule in ways which please the political authorities responsible for elevating judges to higher courts.

39 Nampewo, Z., State Constitutionalism in Uganda: Challenges in Observance, In Lawrence Mute (ed) Constitutionalism in East Africa: Progress, Challenges and Prospects in 2004, Kampala, Fountain publishers, 2007, p.93.

40 Ssuna I., Judges Favour Ssemo, Says Museveni, The Monitor 30,June 2007.

41 Judicial Service Commission Regulations, 2005.

42 Karuhanga v. Attorney General Constitutional Petition no.39of 2013. 


\section{The Executive in the Promotion of Judges}

It should be noted that a purely political process for selecting new judges can twist the judiciary unduly in favour of the body controlling selections, especially if that body exercises continuing institutional influence on judges' careers. Yet denying the political branches any say in the selection of judges risks isolating the judiciary from the democratic society which it serves and indeed, the potential intrusion is relatively minor as by itself, bias in selection does not restrict the judge's subsequent independence on the bench. Certainly, international standards and member State practice do not prohibit the involvement of the political branches in initial selection of judges. ${ }^{43}$

Although the process of selecting judges can never be completely isolated from political considerations there should be neutral, objective, and transparent standards. The evaluation and promotion as with initial selection procedures, where standards for promotion are not regularized and transparent, promotion and the rewards it brings can be held out as an incentive for a judge to issue rulings pleasing to those deciding which judges advance. ${ }^{44}$ In addition, because high ranking judges review lower court decisions, and often have administrative authority, there are added incentives for political actors to influence the advancement of judges to higher positions if clear and neutral procedures are not in place to prevent them. International standards call for advancement to be based on factors such as experience and ability. ${ }^{45}$ In fact, some of the presidential appointments have surprised the citizens.

For instance, in February 2018, the President appointed a total of 14 judges to the High Court and Court of appeal respectively. This was in response to the persistent complaints by the judiciary about shortages of judges to tackle the staggering case backlog. Those promoted to the Court of Appeal include; Justice Christopher Madrama, Steven Musota, Percy Tuhaise and Ezekiel Muhanguzi who recently retired as High Court Judge after clocking 65 years of age. Those appointed to the High Court Bench include; Chief registrar Paul Gadenya, Chief Magistrate Joyce Kavuma, Deputy Registrars Olive Kazaarwe Mukwaya, Alex Ajiji, Tadeo Asiimwe and Emanuel Baguma. Others include; High Court advocate Musa Sekaana, Richard Wabwire, State Attorney, Jane Abod, Cornellia Sabiti, the former executive director of the the public procurement and disposal of public assets authority. This shows a diverse range of promotions from various backgrounds. ${ }^{46}$

Ordinarily, judicial posts on the bench are usually filled by career judges who are progressively promoted. The assessments for promotion should be made on objective criteria such as the judge's integrity, ability to performance and experience. There are considerable differences in the precision and clarity with which criteria for assessing performance are de-

43 Compare UN Basic Principles, Art. 10 (requiring that appointees be persons of "integrity and ability" and that selection not be for "improper motives" or discriminatory);

44 Supra.

45 UN Basic Principles, Art. 13.

46 Retrieved from the Judiciary Website. 
fined. Therefore, the absence of clear promotion criteria increases the risk of arbitrary and politically biased promotional decisions. ${ }^{47}$

However, unless proper safeguards are in place, the discretion which inevitably attaches to the decision affecting the judge's career provides opportunities for other actors to punish or reward judges based on the substance of rulings. It should be noted that there are judges who have been left out because of not deciding cases in favour of the ruling party, NRM. For example, Justice Kanyeihamba one of Uganda's best and former supreme court judge, in his book "The Blessings and Joy of Being Who You are" 48 decried how the executive victimized him for not interpreting the law in favour of the ruling party. Though deserving, Kanyeihamba was never elevated to the level of Chief Justice or even recommended for an international deployment let alone heading a commission of inquiry.

\section{Absence of Transparency in the Promotion Process}

Some members of the legal fraternity opine that the process of appointment and promotion should be open to public scrutiny. The process being closed raises a lot of questions. The process of appointing and promoting judicial officers, most especially for those in the higher bench should be transparent to attract more public scrutiny. In so doing, it would increase the legitimacy for those holding the offices and it would help them enjoy public trust. ${ }^{49}$

Other lawyers I interviewed said that the laws should be amended so that promotion of judicial officers is more on merit. Whereas no system is perfect, some excellent judges are left out for one reason or the other. I do not know why some judges are overlooked by the president, the respondent lamented. A lot happens and I am not in position to explain what goes on..$^{50}$

\section{High Levels of Interference by the Executive in the Appointment, Promotion and Remuneration of Judges}

There is high level of interference by the executive in the judiciary. Where judges have made decisions that affect the interest of the ruling party (NRM) adversely, the repercussion is that; such a judge can never be promoted or recommended to work in international forums. The impact of the repercussions of a judge's decision can be predicted from a recent fiercely contested constitutional petition which inter alia challenged the proposal to remove presidential age limit and lift the parliamentary term from 5 to seven years. This decision

47 Interview with a Justice of the Court of Appeal, 30/10/2018.

48 Kanyeihamba, G.W., The Blessings and Joy of Being Who You are, 2012, ISBN-10:9970907506.

49 Supra.

50 An interview with a member the JSC. 
was of paramount significance to the political direction of Uganda. ${ }^{51}$ A case in point is Mabirizi \& Ors v. $\mathbf{A G}^{52}$ the dissenting Justice Kenneth Kakuru was highly hailed by Ugandans for his courageous ruling where he inter alia stated that;

"The age Limit Bill appeared to have been well planned and premeditated by a few backbenchers with the support of the Attorney General. I find that there was no public participation. I find no reasonable justification for the MPs to award themselves two years on top of the five without consulting their electorates. Parliament could as well abolish the judiciary, vote to remove the republic of Uganda and make themselves parliamentarians for life. Parliament may every five years as set out in the impugned Act, extend its term without having to go for elections, perpetually. Even worse, it could abolish elections and declare its current members to be members for life! Parliament could even abolish the judiciary and vest judicial powers in itself. It could repeal the whole bill of rights from the constitution as long as it has majority to do so. It could even abolish the republic of Uganda and in its stead create a monarchy. Once the principle is set that Parliament has a right to amend any article in the constitution, simply by voting "yes", there would be no limit to their demands. Nothing would stop them from amending the constitution to provide that they would be members of parliament for life and upon death, their parliamentary seat be inherited by their children. They cannot do so because the constitution put in place this court to stop them. This court shall not stand by and let our country's democracy and hard worn values set out in the constitution wither in vein. It will not happen on our watch." ${ }^{53}$

Other judges who have been sidelined in promotions include; Justice Kasule 69, joined the Judiciary as High Court Judge in 2004 after an illustrious career in private practice. He served in Kampala and as a resident judge in Gulu from 2007 to 2911 before he was promoted to the Court of Appeal. He has written several groundbreaking judgments, but he is publically more remembered for his dissenting judgment in the case of the four expelled NRM MPs. ${ }^{54}$ Kasule is also the current chairperson of the Uganda Law Council, a body that ensures that legal practitioners act with the professional standards. Justice Kasule served at the Court of Appeal for a considerable number of years without promotion. ${ }^{55}$ Justice Kasule

51 Batte, B, Age Limit: Who can rule Against NRM, July 25 2018, the Observer (retrieved from observer.org/news/headlines/58274-age-limit-judges-who-can-rule-agaainst-nrm.html. In that Petition, President Museveni who would be over 75 years age limit at the next election, is a singular beneficiary of the amendment. Critics point out that the amendment opened the door for him to become a life president. The petitioner challenged the legality of the amendment as unconstitutional. The government in preparation to remove the article on presidential age limit had paid of MPs, the staging of a very violent attack on parliament by soldiers from the presidential guard, and an unprecedented beating up of MPs in the House precincts which left some like Mukono Municipality Betty Nambooze hospitalized with life threatening injuries.

52 Consolidated Constitutional Petitions No.s 49 of 2017, 3 of 2018, 5 of 2018, 10 of 2018, \& 13 of 2018.See also: Memorable quotes in age limit case ruling, Monitor Sunday July 292018.

53 Supra.

54 Theosore Ssekikubo \&4 Ors v. Joseph Kwesiga Constitutional Petition No.21 of 2013.

55 Supra. 
is highly regarded by the citizens for making fundamental decisions in his constitutional interpretation. Some of these decisions were not in favour of the ruling party hence the reason for his prolonged stay at the court of appeal. In 2011, Justice Kasule and others quashed former vice president Gilbert Bukenya arguments that he couldn't be charged by the Inspector General of Government for the offences of abuse of office before the anti-corruption court. The charges leveled against him were based on actions done in his official capacity as the vice president.

In the same year, Kasule with others ordered that the trial of the former Lord's Resistance Army fighter Thomas Kwoyelo was inconsistent with the constitution as it deprived him of equal treatment under the Amnesty Act. Kwoyelo's co-accused had been granted amnesty. ${ }^{56}$

A year later, Kasule ruled in a petition filed by one Severino Twinobusingye ${ }^{57}$ that Parliament's order for minister's Amama Mbabazi, Sam Kutesa and Hilary Onek to step aside pending investigations by an ad hoc committee into corruption allegations in the oil sector was unconstitutional and therefore, null and void. Kasule with others also set notable precedent when he ruled that the inspectorate of Government cannot prosecute or cause prosecution in cases involving corruption, abuse of authority in public office when it is not dully constituted. Foreign affairs minister Kuteesa who had been dragged to court by the then acting IGG Raphael Baku for alleged corruption during 2007 commonwealth heads of government meeting preparations, had challenged his trial in the constitutional court.

And in 2018 Kasule, power to amend is within the constitution, but should not be used to create a situation where the power to amend can be outside the constitution. ${ }^{58}$ As such, Kasule has only watched his colleagues ascend higher the Bench by promotion while leaving him behind. This is because promotion depends on allegiance to ruling party. In spite his fate, the relentless judge soldiers on.

Whereas in the past judicial officers were promoted on merit depending on the number of years they had served and whether they had no criminal record. This is no longer the state of affairs as promotions are craftly designed to take into consideration the interests of the ruling party NRM. With the appointment of the former Deputy Chief Justice Hon. Steven Kavuma famously referred to as a cadre judge, (appointed from the military) any citizen could predict the results of case involving the ruling party taken to the constitutional court. Indeed he lived truly to the prediction of the Ugandan.

Judges have also been selected from a wide range of arenas ranging from advocates from legal practice, heads of government departs and the academia among others. ${ }^{59}$ This

56 Uganda v. Kwoyelo Constitutional Pet.No. 3 pf 2011.

57 Soverino Twinobusingye v. Attorney General Constitutional Petition No. 47 of 2011.

58 Mabirizi Case (supra).

59 For example Justice Prof. Tibatemwa Ekirikubinza, was appointed to the Court of Appeal. She had previously been serving as the Dean and Lecturer of Law at Makerere and Uganda Christian Uni- 
however well-intentioned has frustrated those who have served for very many years with their hopes of ever being promoted remaining a dream.

In an interview with one judicial officer who started serving the judiciary twenty years ago in a remote court Magistrate Grade One Court. Todate, he is still serving in the same capacity with no salary increment and of course no promotion. In spite of his several attempts in applying to be considered for promotion, his efforts have remained futile the Magistrate narrated. He explained that very many low ranking judicial officers fall in this category. ${ }^{60} \mathrm{He}$ added that promotion depends on whose son or daughter one is or whether one is known to powerful government officials. He also cited some recent entrants into the judiciary who have been promoted very quickly and taken to urban courts because they are children of important government individuals. ${ }^{61}$

In 2015, President Museveni named judges to the Constitutional Court and Supreme Court, drawing praise for some choices, but he was criticized for persistently ignoring some candidates recommended to him. ${ }^{62}$ The President promoted five justices of the Court of Appeal to the Supreme Court namely; Augustine Nshimye, Lilian Tibatemwa, Faith Mwondah, Eldad Mwangysya and Ruby Opio Aweri. The new judges filled gaps on the bench following the retirement of justices Benjamin Odoki, John Wilson Tsekooko, Galdino Okello and Christine Kitumba. Seven more judges were appointed to the Court of Appeal: Alfonso Owinyi Dollo, Elizabeth Musoke, Paul Mugambwa, Simon Byabakama, Catherine Bamugemereire, Cheborion Barishaki and Hellen Obura.

The Observer, noted that some judicial officers recommended by JSC had been ignored again by the president. ${ }^{63}$ Although those who were selected have the requisite qualifications, it is also strange that justices with proven records were rejected. A judicial officer said. Accordingly, thev senior judges who sat interviews but were passed over include; Remmy Kasule, Steven Martin Engonda-Ntende, Geofrey Kiryabwire, and Solomy Barungi Bossa. Justice Kasule confirmed that he and his colleagues sat promotional interviews to the Supreme Court by were intentionally left out by the executive. "Almost all Court of Appeal Judges sat interviews but the results never favoured me he said." Prof. Fredrick Sempebwa, who represents the Uganda Law Society on the JSC, confirmed that both Kasule and Engonda Ntende's names have been submitted several times to the president for promotion to

versity. The recent appointments also saw Justice Ssekaana Musa, an author and a Law Lecturer at Uganda Christian University and Islamic University of Uganda appointed to the High Court. Other Justices have been selected from those in Legal Practice for instance Justice Kenneth Kakuru and Catherine Bamugemereire of the Court of Appeal. This however well-intentioned has frustrated those who have served for very many years with their hopes of ever being promoted remaining a dream.

60 Interview with a Magistrate Grade One on 14/10/2018.

61 Ibid.

62 Sulaimani, K., \& Kiyonga, D., Museveni's Choice of Judges for Promotion Raises Questions, The Observer, September 16, 2015.

63 Supra. 
the Supreme Court but they have been ignored. Having submitted many names, out of these names the President chose the five and there is nothing we can do about it he said. ${ }^{64}$

\section{Conclusion}

In light of the above discussion, remuneration, promotion and reward of efficient and independent judges are a back-borne to judicial independence. Nevertheless, remuneration, promotion and reward of an efficient judge are largely dependent on paying allegiance to the executive and decide cases to appeasement of the executive. Yet, remuneration, promotion and reward are supposed to be on merit. They should also be established by law and not subject to arbitrary interference from the executive. This study has points out how the executive has substantial impact on remuneration, promotion and reward of efficient judges. Judges that decide cases according to the law irrespective of the interests of the executive are sidelined in the promotions, remunerations and reward.

\section{E. Recommendations}

I. The procedures for regulating the course of a judge's career from appointment through various promotions to retirement should properly be insulated from political considerations.

II. The continuing assumption that political involvement in judicial administration is necessary and desirable must be confronted and rejected.

64 Justice Egonda Ntende 62, was a Chief Justice of the republic of Seychelles from 2009 to 2013. Before that he served in the High Court and was co-opted to the panel of the Court of Appeal and Supreme Court of Uganda.He was promoted to the Court of Appeal in 2013. Ntende was part of the Court of Appeal Panel in the David Tinyefuza Case in which he and other judges ruled that Tinyefuza had a right to retire from the army. According to the JSC, Uganda Law Society has lobbied for Kasule and Ntende to be appointed to the Supreme Court. Justice Bossa is a former Lecturer at Law Development Center for 1980 to 1997. She also has previously served as President of the Uganda Law Society (1993-1995) and is the founding president of the East African Law Society (1994-197) During that time, she was an activist lawyer with a bias towards human rights and constitutional law. For instance, she challenged the procedure which the kingdoms were restored. She was a founding chairperson of Kituo cha Katiba (1996-2003). She joined judiciary in 1998 as a judge of the High Court. Since then she served in various capacities having been posted to the east African Court of Justice and the United Nations International criminal Tribunal for Rwanda. Bossa is married to UPC Vice President Joseph Bosa, holds a master degree in international public law from university of London. For Justice Kiryabwire, he was previously a judge at the commercial decision of the High Court. He joined the bench in 2002. He enrolled as an advocate of the High Court in 1987 and holds a Master of Laws degree (with a bias in International Economic Law from the University of London. He has been a member of three commissions of inquiry into the mismanagement of criminal case, the collapse of the three commercial banks and the junk helicopter purchase. 
III. Politicians must publicly affirm the importance of an independent judiciary by enacting legislation supporting it, and refrain from making inroads on the judiciary's prerogatives.

IV. Judges must refute political criticism by demonstrating that they are prepared to deliver justice with professionalism and restraint and remain accountable to society.

V. Dividing the selection process into nominating and appointing phases, with different bodies or branches responsible for each phase, can limit the risks of undue political influence.

\section{REFERENCES}

The Constitution of Republic of Uganda, 1995

Salaries \& Allowances (Specified Officers) Act 1999

Employment Act, 2006

Labour Unions Act No. 7 of 2006

Equal Opportunities Commission Act, No.2 of 2007

UN Basic Principles

Alexander Hamilton, The Federalist No 78, 'The Judiciary Department' Independent Journal. (Saturday, June 14, 1788).

Asiimwe, J., Towards God Governance in Uganda: A Critical Analysis of the Role Played By Judiciary in Promoting Rule of law from a Constitutional Perspective, Dissertation, University of Dar es Salaam, August, 2013.

Equal Opportunities Commission, Study Report on Salary Disparities in the Public Service, May 2017, Kampala, Uganda (retrieved from; final_salary_disparity_report.pdf.)

Holdsworth LQR p 33. See, Ramon Mullerat OBE "The Judges Independence from his own Convictions" in The Indian Advocate: Journal of the Bar Association of India: Vol XXXII 2004 p 88.

Kanyeihamba, G.W., Kanyeihamba's Commentaries on Law, Politics and Governance, Renaissance Media Ltd,2006, Kampala, p.67.

Kanyeihamba, G.W., The Blessings and Joy of Being Who You are, 2012, ISBN-10:9970907506.

Nampewo, Z., State Constitutionalism in Uganda: Challenges in Observance, In Lawrence Mute (ed) Constitutionalism in East Africa: Progress, Challenges and Prospects in 2004, Kampala, Fountain publishers, 2007, p.93.

Ssuna I., Judges Favour Ssemo, Says Museveni, The Monitor 30,June 2007.

Sulaimani, K., \& Kiyonga, D., Museveni's Choice of Judges for PromotionRaises Questions.

The Observer, September 16, 2015. 